\title{
OPTIMALISASI MANAJEMEN SARANA DAN PRASARANA DALAM MENUNJANG AKTIFITAS BELAJAR SISWA SMA NEGERI 1 AIKMEL
}

\author{
Fizian Yahya, Handayani \\ (STAI) Darul Kamal NW Kembang Kerang NTB \\ Email: fizian1989@gmail.com, handayanihani111@gmail.com
}

\begin{abstract}
Abstrak
Penelitian ini bertujuan untuk mengetahui bagaimana bentuk dari pelaksanaan manajemen sarana dan prasarana pendidikan dalam menunjang aktifitas belajar siswa yang ada di SMA NEGERI 1 AIKMEL. Adapun jenis penelitian yang digunakan dalam penelitian ini adalah penelitian kualitatif lapangan (Field Research) dengan kepala sekolah dan wakil sarana dan prasarana SMA NEGERI 1 AIKMEL sebagai informan dalam penelitian. Metode yang digunakan dalam pengumpulan data adalah metode observasi, wawancara, dan dokumentasi. Sedangkan analisis yang digunakan dalam penelitian ini adalah deskriptif dimana peneliti terjun langsung ke lapangan guna mempelajari, menganalisis, dan menarik kesimpulan dari fenomena yang ada. Analisis penelitian kualitatif ini dilakukan bersama dengan proses pengumpulan data.

Hasil penelitian ini menunjukkan bahwa pelaksanaan manajemen sarana dan prasarana pendidikan yang ada di SMA NEGERI 1 AIKMEL sudah dilaksanakan dengan sangat baik, karena dilakukan sudan sangat teratur sesuai dengan fungsi manajmen yang meliputi: perencanaan, pengadaan, pemeliharaan, serta penghapusan sarana dan prasarana pendidikan.
\end{abstract}

Kata kunci: manajemen, sarana dan prasarana, aktivitas belajar

\section{Pendahuluan}

Dari observasi yang dilakukan di SMA NEGERI 1 AIKMEL kami melihat bahwa mengenai sarana dan prasarana yang dimiliki sudah lengkap dan bisa memenuhi segala kebutuhan siswa-siswinya dalam menunjang aktifitas proses belajar mengajar, baik itu dari segi ruang kelas yang berjumlah 27, ruang belajar 24, laboratorium, perpustakaan, tempat beribadah, lapangan olahraga, kantin, kebun dan taman sekolah sekaligus dijadikan tempat pembelajaran ataupun praktik biologi, tempat parkir, media pembelajaran yang lengkap serta lingkungan sekolah yang sejuk dan nyaman.

Keberhasilan program pendidikan melalui proses pembelajaran sangat dipengaruhi oleh banyak faktor, salah satu diantaranya adalah tersedianya sarana dan prasarana pendidikan yang memadai disertai pemanfaatan dan pengelolaan secara optimal. Kelengkpan dan ketersediaan fasilitas pendidikan di sekolah sangat 
berpengaruh terhadap keefektifan dan kelancaran pembelajaran di ruang kelas. Sarana dan prasarana pendidikan adalah salah satu sumber daya yang penting dan utama dalam menunjang proses pembelajaran di sekolah, untuk itu perlu dilakukan peningkatan dalam penggunaan dan pengelolaannya, agar tujuan yang diharapkan dapat tercapai secara efektif dan efesien.

Sedangkan secara sederhana, manajemen perlengkapan pendidikan sekolah dapat didefinisikan sebagai proses kerjasama pendayagunaan semua perlengkapan pendidikan secara efektif dan efesien. ${ }^{1}$ Berdasarkan definisi tersebut maka pada hakikatnya manajemen sarana dan prasarana pendidikan di sekolah itu merupakan proses pendayagunaan semua sarana dan prasarana yang dimiliki sekolah. Semua fasilitas atau sarana dan prasarana sekolah haruslah dikelola dengan baik agar keberadaan sarana dan prasarana tersebut dapat menunjang proses pembelajaran di kelas dapat berjalan lancar dan tujuan pendidikan dapat terujud. Dalam kegiatan pembelajaran sarana dan prasarana sangat diperlukan dalam rangka menunjang kelancaran proses kegiatannya, sehigga pengelolaan sarana dan prasarana sangat diperlukan oleh setiap instansi terutama di sekolah.

Bagaimana bentuk manajemen sarana dan prasarana pendidikan dalam menunjang aktifitas belajar siswa yang ada di SMA NEGERI 1 AIKMEL?

\section{Manajemen}

1. Pengertian Manajemen

Manajemen secara etimologis berasal dari bahasa inggris yaitu dari kata kerja to manage yang artinya mengurus, mengatur, melaksanakan dan mengelola. ${ }^{2}$ Manajemen secara bahasa berarti bagaimana proses mengurus, mengatur, melaksanakan dan mengelola kegiatan-kegiatan dalam sebuah instansi atau organisasi untuk mencapai tujuan yang telah ditetapkan.

Manajemen adalah ilmu dan seni mengatur proses pemanfaatan sumber daya manusia dan sumber-sumber lainnya secara efektif dan efesien untuk mencapai suatu tujuan tertentu. ${ }^{3}$ Management is the coordination of all resources through the processes of planning, organizing, directing, and controlling in order to attain stated objectives. ${ }^{4}$ Manajemen diartikan sebagai koordinasi semua sumber tenaga melalui proses perencanaan, pengorganisasian, pemberian bimbingan dan pengendalian untuk mencapai tujuan yang telah ditetapkan.

\footnotetext{
${ }^{1}$ Bafadal, Manajemen Perlengkapan Sekolah. (Jakarta:Bumi Aksara, 2008), hlm. 103.

2 Echols dan Shadily, Kamus Inggris Indonesia, (Jakarta: PT. Gramedia, 2005), hlm. 372.

${ }^{3}$ Hasibuan, Manajemen Dasar, Pengertian, Dan Masalah, (Jakarta: Bumi Aksara, 2007), hlm. 2.

${ }^{4}$ Henry, Principles of Management: a System Approach to the Management Process, (England: South-Western Publishing Company, 1999), hlm. 10
} 
Sedangkan makna manajemen yang disebutkan di dalam sebuah hadits yang artinya sebagai berikut : "Dari Abu Hurairah ra. Berkata: Rasulullah SAW bersabda: apabila suatu urusan diserahkan kepada yang bukan ahlinya, maka tunggulah kehancuran." (HR. Bukhari). ${ }^{5}$

Hadits diatas menunjukkan betapa Islam sangat menekankan pentingnya manajemen dan kepemimpinan dalam setiap aktivitas, termasuk di dalamnya aktivitas pendidikan. Suatu aktivitas akan berjalan dengan lancer dan teratur apabila didasarkan pada manajemen yang sehat dan didukung oleh kepentingan yang tepat dan handal. ${ }^{6}$

Uraian diatas dapat disimpulkan bahwa manajemen adalah sebagai proses merencanakan, mengorganisasikan, menggerakkan, mengawasi, dan mendayagunakan seluruh sumber daya yang di miliki organisasi dalam rangka untuk mencapai tujuan organisasi secara efektif dan efesien.

Ada tiga hal penting yang perlu diperhatikan dari definisi manajemen, yaitu proses, pendayagunaan seluruh sumber organisasi dan pencapaian tujuan organisasi yang telah ditetapkan.

a. Proses ialah suatu cara yang sistematik dalam mengerjakan suatu manajemen sebagai suatu proses, karena semua manajer dengan ketangkasan dan keterampilan yang khusus, mengusahakan berbagai kegiatan yang saling berkaitan dan dapat didayagunakan untuk mencapai tujuan yang telah direncanakan. Kegiatan tersebut meliputi merencanakan, mengorganisasikan, memimpin, melaksanakan, mengendalikan dan mendayagunakan.

b. Sumber daya organisasi meliputi dana, perlengkapan, informasi maupun sumber daya manusia yang masing-masing berfungsi sebagai pemikir, pelaku serta pendukung untuk mencapai tujuan.

c. Mencapai tujuan organisasi yang telah ditetapkan sebelumnya. ${ }^{7}$ Pada dasarnya setiap aktivitas atau kegiatan selalu mempunyai tujuan yang ingin dicapai, dimana tujuan individualnya ialah untuk dapat memenuhi kebutuhan-kebutuhan berupa materi dan non materi dari hasil kerja yang telah dilakukan.

2. Prinsip Manajemen

Prinsip-prinsip dasar dalam praktik manajmen antara lain menentukan metode kerja, pemilihan pekerjaan, pengembangan keahlian, pemilihan prosedur kerja,

${ }^{5}$ Imam Bukhori, Shohih Bukhori, Juz I, (Bairut: Daar Al Kutub, 1994), hlm.24.

${ }^{6}$ Habib Thoha, PBM DAI di Sekolah (Eksistensi dan PBM PAI), (Yogyakarta: Pustaka Pelajar, 1998), hlm. 135.

${ }^{7}$ Wahyosumidjo, Kepemimpinan Kepala Sekolah. Tinjauan Teoritik dan Permasalahannya, (Jakarta: Raja Grafindo Persada, 2001), hlm. 93-95. 
menentukan batas-batas tugas, mempersiapkan dan membuat spesifikasi tugas, melakukan pendidikan dan latihan, melakukan system dan besarnya imbalan itu dimaksudkan untuk meningkatkan efektivitas, efesiensi, dan produktivitas kerja. ${ }^{8}$

Adapun prinsip dasar manajmen yang lain diantaranya : pembagian kerja, disiplin, otoritas, keadilan, teratur, inisiatif, kesatuan perintah, dan semangat kelompok. Semangat kelompok merupakan kekuatan terbesar yang dimiliki oleh suatu isnstansi atau organisasi, karena apabila semangat kelompok hilang maka organisasi atau instansi tersebut tidak akan berjalan dengan lancar dan tidak dapat mencapai tujuan yang telah direncanakan secara efektif dan efesien.

3. Fungsi-Fungsi Manajemen

Fungsi-fungsi manajemen adalah elemen-elemen dasar yang akan selalu ada dan melekat di dalam proses manajemen yang akan di jadikan acuan oleh manajer dalam melaksanankan kegiatan untuk mencapai tujuan. ${ }^{9}$ Sedangkan menurut pendapat yang lain bahwa fungsi-fungsi manajemen adalah serangkkaian sub bagian tubuh yang berada di manajemen sehingga bagian-bagian tubuh tersebut dapat melaksanakan fungsi dan mencapai tujuan organisasi. Fungsi-fungsi manajemen terdiri dari perencanaan (planning), pengorganisasian (organizing), penggerakan (actuating), pengawasan (controlling). ${ }^{10}$

Dari definisi tersebut dapat disimpulkan bahwa, fungsi-fungsi manajemen adalah serangkaian bagian-bagian dalam manajemen yang harus diaplikasikan sehingga tujuan serta visi dan misi organisasi sekolah, perusahaan dapat tercapai secara efektif dan efesien. Adapun bagian-bagian dalam manajemen tersebut lebih dikenal dengan (POAC) perencanaan (planning), pengorganisasian (organizing), penggerakan (actuating), pengawasan (controlling).

a. Perencanaan (planning)

Perencanaan merupakan unsur yang sangat penting dan merupakan fungsi fundamental manajemen, karena organizing, actuating dan controlling harus terlebih dahulu direncanakan. Adapun pengertian perencanaan adalah kegiatan memilih dan menghubungkan asumsi-asumsi mengenai masa yang akan datang dalam hal memvisualisasi serta merumuskan aktifitas-aktifitas yang diusulkan dan dianggap perlu untuk mencapai hasil-hasil yang diinginkan. ${ }^{11}$

\footnotetext{
${ }^{8}$ Fattah, op. cit., hlm. 12.

${ }^{9}$ Malayu, Manajemen Dasar, Pengertian dan Masalah (Jakarta: Gunung Agung, 1989), hlm.198.

${ }^{10}$ Terry, Asas-Asas Manajemen (Bandung:Alumni,1986), hlm.163.

${ }^{11}$ Sondang, Fungsi-Fungsi Manajemen (Jakarta:Bumi Aksara, 2012), hlm. 36.
} 
Adapun perencanaan menurut dimensi waktu dibagi menjadi tiga yaitu antara lain:

1) Perencanaan Jangka Panjang

Perencanaan jangka panjang biasanya mempunyai jangka waktu lima sampai sepuluh tahun bahkan lebih, tergantung besar tidaknya suatu perusahaan, organisasi maupun lembaga itu sendiri. Perencanaan jangka panjang memuat rencana-rencana yang umum, global serta belum terperinci.

2) Perencanaan Jangka Menengah

Perencanaan jangka menengah biasanya mempunyai jenjang waktu dua sampai lima tahun. Perencanaan jangka menengah merupakan repeletika dari perencanaan jangka panjang. Didalamnya tercantum tujuan dan target secara lebih jelas sehingga memberikan dasar-dasar yang pasti bagi kegiatan yang direncanakan.

3) Perencanaan Jangka Pendek

Perencanaan jangka pendek biasanya mempunyai jangka waktu satu tahun sampai tiga tahun. Salah satu yang sering kita temukan dari perencanaan jangka pendek adalah rencana tahunan. Perencanaan tahunan sering juga disebut perencanaan operasional dan merupakan suatu siklus yang berulang setiap tahunnya.

Dari definisi tersebut dapat disimpulkan bahwa perencanaan adalah suatu kegiatan membuat urutan-urutan tentang tindakan yang akan dilaksanakan agar tujuannya dapat tercapai secara efektif dan efesien. Dalam perencanaan harus diusahakan untuk menjawab enam pertanyaan yaitu: apa yang harus dikerjakan, dimana ia harus dikerjakan dan kapan harus dikerjakan. Karena perencanaan yang baik akan memperlancar proses visi dan misi perusahaan.

b. Pengorganisasian (organizing)

Pengorganisasian merupakan serangkaian pekerjaan yang melibatkan banyak orang untuk menempati unit-unit tertentu, seperti kerja-kerja manajerial, teknis dan lain sebaginya. ${ }^{12}$

Pengorganisasian adalah suatu proses penentuan pengelompokan dan pengaturan bermacam-macam aktivitas yang diperlukan untuk mencapai tujuan, menempatkan orang-orang pada setiap aktivitas, menetapkan

${ }^{12}$ Juliatriasa Dan Suprihanto, Manajemen Umum Sebuah Pengantar, (Yogyakarta: BPFF, 1998), hlm. 14. 
wewenang yang secara relative didelegasikan kepada setiap individu yang akan melakukan aktivitas-aktivitas tersebut. ${ }^{13}$

Jika kita menggunakan pengorganisasian dengan pengertian dan pendekatan di atas maka akan terlihat ada empat tipe model pengorganisasian sebagai berikut: ${ }^{14}$

1) Pengorganisasian Lini

Tipe pengorganisasian lini merupakan tipe simpl dan hanya membutuhkan bidang atau anggota yang sangat sedikit.

Adapun tipe ini memiliki ciri-ciri sebagai berikut.:

a) Organisasi berukuran kecil

b) Jumlah karyawan sedikit

c) Komunikasi pimpinan dan bawahan bersifat langsung

d) Saling mengenal secara pribadi

e) Struktur organisasi sederhana

f) Pemilik menjadi pimpinan tertinggi

g) Tujuan yang dicapai tidak terlalu rumit.

Dari uraian diatas dapat disimpulkan bahwa organisasi dapat dikatakan baik jika prinsip pengorganisasiannya dapat dilakukan sepenuhnya. Agar pengorganisasian berjalan lancar, efektif dan efesien seorang manajer atau pimpinan (kepala sekolah) harus memperhatikan prinsip pengorganisasian yang ada di dalam organisasinya.

c. Penggerakan (Actuating)

Penggerakan (Actuating) merupakan usaha menggerakkan anggotaanggota kelompok sedemikian rupa hingga mereka berkeinginan dan berusaha untuk mencapai sasaran perusahaan dan sasaran anggota-anggota perusahaan tersebut oleh karena para anggota itu juga ingin mencapai sasaran-sasaran tersebut. ${ }^{15}$

Actuating juga diartikan implementasi dari apa yang direncanakan dalam fungsi planning dengan memanfaatkan persiapan yang sudah dilakukan organizing. ${ }^{16}$

Dari pengertian di atas disimpulkan bahwa penggerakan (actuating) merupakan usaha untuk menjadikan perencanaan menjadi kenyataan, dengan melalui berbagai pengarahan dan pemotivasian agar setiap karyawan dapat

\footnotetext{
${ }^{13}$ Hasibuan, Manajemen Dasar, Pengertian dan Masalah (Jakarta: Gunung Agung, 1989), hlm. 221.

${ }^{14}$ Sondang. Fungsi-Fungsi Manajemen, (Jakarta: Bumi Aksara. 2012), hlm. 36.

${ }^{15}$ Sudrajat, Konsep Manajemen Sekolah, http://akhmadsudrajat.wordpress.com/ 2008 / 02/03/KonsepManajemen-Sekolah/

${ }^{16}$ Wibowo, Manajemen Perubahan, (Jakarta: Raja Grafindo Persada, 2006), hlm. 13.
} 
melaksanakan kegiatan secara optimal sesuai dengan peran, tugas dan tanggung jawabnya.

d. Pengawasan (Controlling)

Pengawasan adalah proses penentuan, apa yang harus dicapai yaitu standar, apa yang sedang dilakukan yaitu pelaksanaan, menilai pelaksanaan, dan apabila perlu melakukan perbaikan-perbaikan sehingga pelaksanaan sesuai dengan rencana yaitu selaras dengan standar. ${ }^{17}$

Pengawasan dapat juga diartikan sebagai proses monitoring kegiatankegiatan, tujuannya untuk menentukan harapan-harapan yang akan dicapai dan dilakukan perbaikan-perbaikan terhadap penyimpangan-penyimpangan yang terjadi. Harapan-harapannya dimaksud adalah tujuan-tujuan yang telah ditetapkan untuk dicapai dan program-program yang telah direncanakan untuk dilakukan dalam priode tertentu. ${ }^{18}$

Fungsi pengawasan meliputi penentuan standar, supervisi dan mengukur penampilan atau pelaksanaan terhadap standard an memberikan keyakinan bahwa tujuan organisasi tercapai. Pengendalian sangat erat kaitannya dengan perencanaan, karena melalui pengendalian efektivitas manajemen dapat diukur. $^{19}$

Dengan demikian disimpulkan bahwa pengawasan merupakan suatu kegiatan ynag berusaha untuk mengendalikan supaya proses pelaksanaan yang dilakukan sesuai dengan ketentuan-ketentuan dari rencana, dan memastikan apakah tujuan organisasi tercapai. Apabila terdapat penyimpanganpenyimpangan (deviasi) maka segera mencari letak penyimpangan tersebut kemudian melakukan tindakan perbaikan (corrective).

\section{Metode Penelitian}

Kajian ini merupakan penelitian kualitatif (qualitative research) yang bertujuan untuk menggambarkan dan menganalisis fenomena-fenomena, peristiwa, aktivitas sosial, sikap, kepercayaan, persepsi, pemikiran orang secara individu ataupun kelompok. ${ }^{20}$

\footnotetext{
${ }^{17}$ Hasibuan, op. cit., hlm. 242.

${ }^{18}$ Bafadal, Manajemen Peningkatan Mutu Sekolah Dasar; Dari Sentralisasi Menuju Desentralisasi, (Jakarta: Bumi Aksara, 2003), hlm. 46.

${ }^{19}$ Nanang Fattah, op. cit., hlm. 2.

${ }^{20}$ Nana Syaodih Sukmadinata, Metode Penelitian Pendidikan, (Bandung: PT Remaja Rosdakarya, 2006), hal. 60
} 
Teknik pengumpulan data menggunakan observasi, wawancara dan dokumentasi. observasi dilakukan dengan cara mengamati secara langsung sarana dan prasarana yang ada di SMA Negeri 1 Aikmel dalam menunjang prestasi belajar siswa. Wawancara ini digunakan untuk mengambil data tentang manajemen sarana dan prasarana pendidikan dalam menunjang aktifitas belajar siswa di SMA Negeri 1 Aikmel dan dengan melakukan wawancara langsung kepala sekolah dan wakil bidang sarana dan prasarana. Dokumentasi digunakan untuk memperoleh catatan atau arsip yang berkaitan dengan kajian yang berasal dari dokumentasi di SMA Negeri 1 Aikmel.

\section{Hasil dan Pembahasan}

Dari Hasil wawancara dengan Kepala Sekolah dan wakil kepala sekolah bidang sarana dan prasarana, ada beberapa kegiatan dalam manajemen sarana dan prasarana di SMA Negeri 1 Aikmel meliputi:

1. Perencanaan Sarana Prasarana

Perencanaan adalah kegiatan memilih dan menghubungkan asumsi-asumsi mengenai masa yang akan datang dalam hal memvisualisasi serta merumuskan aktifitas-aktifitas yang diusulkan dan dianggap perlu untuk mencapai hasil-hasil yang diinginkan. ${ }^{21}$

Adapun proses perencanaan sarana dan prasarana pendidikan yang ada di SMA NEGERI 1 AIKMEL dilakukan dalam beberapa tahapan diantanya: pembentukan tim dan pembagian tugas.

a. Kepala sekolah sebagai ketua

b. Wakil kepala sekolah bagian sarana dan prasarana pendidikan sebagai penanggung jawab.

- Bertanggung jawab atas tersedianya sarana dan prasarana yang dibutuhkan sekolah baik yang berhubungan langsung dan mendukung pelaksanaan kegiatan belajar mengajar.

- Bertanggung jawab atas terciptanya lingkungan yang bersih dan nyaman.

- Bertanggung jawab atas tugas intern kepala sekolah apabila tidak ada ditempat sesuai dengan batas-batas kewenangan yang diberikan kepala sekolah

- Bertanggung jawab atas koordinasi dan pengawasan tugas-tugas pekerjaan bidang sarana dan prasarana.

c. Bagian perencanaan

- Identifikasi dan mengannalisis kebutuhan sekolah

${ }^{21}$ Siagian Sondang, Fungsi-Fungsi Manajemen (Jakarta:Bumi Aksara, 2012), hlm. 36. 
- Mengadakan seleksi

- Menyusun konsep program

- pendataan

d. Bagian pengadaan

- Menyusun daftar sarana sekolah yang disesuaikan dengan kebutuhan dan rencana kegiatan sekolah tiap bulan.

- Memperkirakan biaya untuk pengadaan barang tersebut setiap bulan.

- Menyusun rencana pengadaan baarang tersebut menjadi rencana triwulan, tengah tahun, dan kemudian menjadi rencana tahunan.memperkirakan biaya sarana dan prasarana yang direncanakan dengan memperhatikan standar yang telah ditentukan.

- Menetapkan skala prioritas menurut dana yang tersedia, urgensi kebutuhan dan menyusun rencana pengadaan tahunan.

e. Bagian pemeliharaan

- Pembersihan saluran dari sampah dan kotoran

- Pembersihan ruangan-ruangan dan halaman dari sampah dan kotoran.

- Pembersihan terhadap kaca, jendela, kursi, meja dan lain-lain.

- Pembabatan rumput dan semak yang tidak teratur

- Perbaikan sarana dan prasarana yang mengalami kerusakan.

f. Bagian penghapusan

- Membuat daftar barang inventaris yang akan dihapus.

- Menghimpun atau meletakkan barang yang akan diusulkan untuk dihapus pada tempat yang sudah ditetapkan.

- Memeriksa barang yang diusulkan untuk dihapus.

- Meminta persetujuan atau izin tertulis dari menteri keuangan diteruskan kepada biro hukum

2. Pengadaan Sarana Prasarana

Pengadaan sarana dan prasarana pendidikan adalah segala kegiatan untuk menyediakan semua keperluan barang, benda, jasa, bagi keperluan pelaksanaan tugas. ${ }^{22}$

Pengadaan sarana dan prasarana di SMA NEGERI 1 AIKMEL biasanya dilaksanakan sebelum dimulainya tahun pelajaran baru, pengadaan barang dilakukan sesuai dengan pengidentifikasian yang sudah dilakukan dalam perencanaan, jikalau ada barang yang dibutuhkan maka itu diadakan, dan kalau ada kerusakan tinggal dilakukan perbaikan. Dan hal tersebut disusun dalam

${ }^{22}$ Gunawan, Administrasi Sekolah: Administrasi Pendidikan Mikro, (Jakarta: Pt. Rineka Cipta, 1996), hlm. 135 . 
Rencana Kerja Anggaran Sekolah (RKAS) dan baru setelah itu dilaksanakan sesuai dengan penganggarannya, dianggarkan sesuai dengan berapa jumlah dana yang masuk ke sekolah.

3. Pemeliharaan Sarana dan Prasarana

Pemeliharaan atau perawatan adalah kegiatan rutin untuk mengusahakan agar barang tetap dalam keadaan baik dan berfungsi baik pula. ${ }^{23}$

Untuk pemeliharaan sarana dan prasarana ada pembentukan panitia, setiap kegiatan pemeliharaan siswa juga ikut bertanggung jawab. SMA NEGERI 1 AIKMEL mempunyai strategi untuk pemeliharaan sarana dan prasarana di sekolah yaitu salah satunya dengan cara diadakannya lomba kelas, peserta didik dan wali kelas bertanggung jawab menjaga kelas. Penilaiannya dilakukan setiap 6 bulan. Dengan diadakannya lomba ini peserta didik akan lebih bersemangat dalam pemeliharaan kelas yang merupakan bagian dari sarana dan prasarana sekolah.

4. Penghapusan Sarana dan Prasarana

Penghapusan sarana dan prasarana merupakan proses kegiatan yang bertujuan untuk mengeluarkan atau menghilangkan sarana dan prasarana dari daftar inventaris karena sarana dan prasarana tersebut sudah dianggap tidak berfungsi sebagaimana yang diharapkan terutama untuk kepentinganpelaksanaan pembelajaran di sekolah. ${ }^{24}$

Dalam penghapusan barang terlebih dahulu dilakukan identifikasi barang yang rusak, kemudian dilaporkan ke BKAD sesuai dengan struktural. Baru setelah itu turun pemeriksaan dari BKAD untuk melihat apakah kondisinya sesuai dengan yang sudah dilaporkan. Jikalau sudah sesuai maka sekolah akan diberikan surat dan pengahapusan barang bisa dilakukan.

\section{Kesimpulan}

Berdasarkan hasil penelitian mengenai optimalisasi manajemen sarana dan prasarana pendidikan dalam menunjang aktifitas belajar siswa di SMA NEGERI 1 AIKMEL, dapat disimpulkan bahwa kegiatan manajemen sarana dan prasarana pendidikan meliputi perencanaan, pengadaan, pemeliharaan dan penghapusan sarana dan prasarana.

Sarana dan prasarana pendidikan merupakan salah satu faktor penunjang dalam pencapaian keberhasilan proses belajar mengajar di sekolah. Tentunya hal tersebutdapat dicapai apabila ketersediaan sarana dan prasarana yang memadai disertai dengan pengelolaan dan pemanfaatan secara optimal. Untuk

${ }^{23}$ Gunawan, Administrasi Sekolah: Administrasi Pendidikan Mikro, (Jakarta: Pt. Rineka Cipta, 1996), hlm.135.

${ }^{24}$ Minarti, Manajemen Sekolah, (Jogjakarta: AR-Ruzz Media, 2016), hlm.272. 
mengoptimalkan sarana dan prasarana pendidikan, sekolah dituntut memiliki kemandirian untuk mengatur dan mengurus kebutuhan sekolah menurut kebutuhan berdasarkan aspirasi warga sekolah dengan tetap mengacu pada peraturan dan perundang-undangan pendidikan nasional yang berlaku.

Agar sarana dan prasarana pendidikan dapat difungsikan dengan baik, maka diperlukan manajmen sarana dan prasarana pendidikan. Dengan adanya manajemen, maka sekolah akan mampu mengelola sarana dan prasarana pendidikan secara lebih terkonsep dan terarah, sehingga mampu mencapai tujuan secara lebih efektif dan efesien

\section{Daftar Pustaka}

Bafadal. 2008. Manajemen Perlengkapan Sekolah. Jakarta:Bumi Aksara

Echols dan Shadily. 2005. Kamus Inggris Indonesia, Jakarta: PT. Gramedia Hasibuan. 2007. Manajemen Dasar, Pengertian, Dan Masalah, Jakarta: Bumi Aksara Henry. 1999. Principles of Management: a System Approach to the Management Process, England: South-Western Publishing Company Imam Bukhori. 1994. Shohih Bukhori, Juz I, Bairut: Daar Al Kutub Habib Thoha. 1998. PBM DAI di Sekolah (Eksistensi dan PBM PAI), Yogyakarta: Pustaka Pelajar

Wahyosumidjo. 2001. Kepemimpinan Kepala Sekolah. Tinjauan Teoritik dan Permasalahannya, Jakarta: Raja Grafindo Persada

Fattah, op. cit., hlm. 12.

Malayu. 1989. Manajemen Dasar, Pengertian dan Masalah Jakarta: Gunung Agung Terry. 1986. Asas-Asas Manajemen Bandung:Alumni

Juliatriasa Dan Suprihanto. 1998. Manajemen Umum Sebuah Pengantar, Yogyakarta: BPFF

Sondang. 2012. Fungsi-Fungsi Manajemen, Jakarta: Bumi Aksara.

Sudrajat, Konsep Manajemen Sekolah, http://akhmadsudrajat.wordpress.com/ 2008 / 02/03/Konsep-Manajemen-Sekolah/

Sukmadinata, Nana Syaodih. 2006. Metode Penelitian Pendidikan. Bandung: PT Remaja Rosdakarya.

Wibowo. 2006. Manajemen Perubahan, Jakarta: Raja Grafindo Persada

Bafadal. 2003. Manajemen Peningkatan Mutu Sekolah Dasar; Dari Sentralisasi Menuju Desentralisasi, Jakarta: Bumi Aksara

Gunawan. 1996. Administrasi Sekolah: Administrasi Pendidikan Mikro, Jakarta: Pt. Rineka Cipta

Minarti. 2016. Manajemen Sekolah, Jogjakarta: AR-Ruzz Media 